\title{
A Comparative Study of War Crimes Prosecutions by Bosnia and Herzegovina and Serbia
}

\section{Eleanor Whitchurch}

LLM in Criminal Law and Criminal Justice, University of Edinburgh

\begin{abstract}
This paper contrasts the diverging war crimes prosecution efforts of Serbia and of Bosnia and Herzegovina with the aim of determining which factors played a role in the radically different outcomes, and to what extent. It will measure three elements: the effect of international incentives, structural judicial challenges, and ethnic composition, in order to establish which element played the most prominent role in the strikingly lower effectiveness and efficiency of war crimes prosecutions by Serbia in comparison to Bosnia and Herzegovina. The findings suggest that ethnic composition has the strongest influence over the degree to which war crimes prosecutions are pursued, and that this can consequently determine the effectiveness of international incentives. These findings will allow for a better understanding of the success of past post-conflict criminal prosecutions. This enhanced understanding will in turn inform future war crimes prosecutions and help shape measures that could be taken to mitigate the destructive effects of the most prominent spoiling components.
\end{abstract}

Keywords: war crimes, nationbuilding, peacebuilding, transitional justice, international crimes prosecution 


\section{Introduction}

Nearly 25 years after the conclusion of the Bosnian war, in which primarily ethnic Serbs committed large-scale atrocities against predominantly Muslim Bosnians, ${ }^{1}$ Serbia and Bosnia and Herzegovina $(\mathrm{BiH})$ continue to strongly diverge in the intensity of their war crimes prosecution efforts. Upon its closure in 2017, the International Criminal Tribunal for the former Yugoslavia (ICTY), a United Nations-led court, implemented to prosecute war crimes that occurred during the Balkan conflicts of the $1990 \mathrm{~s},{ }^{2}$ observed a profound lack of cooperation from Serbia, which stood in stark contrast with the commitment to promoting criminal accountability.

Regarding Serbia, the ICTY noted that "positive results in war crimes investigations and prosecutions remain very limited," "impunity for many well-established crimes remains the norm" 4 and "the absence of political will to cooperate with the Tribunal further calls into question the country's commitment to justice for war crimes and its adherence to the rule of law." In contrast, it stated that $\mathrm{BiH}$ "continued to investigate and prosecute complex cases... including cases involving senior- and mid-level suspects" $"$ and that "these results demonstrate again that national prosecutions, appropriately supported by international partners, can meaningfully advance accountability.",

Against this background, this paper evaluates Serbian and $\mathrm{BiH}$ war crimes prosecution efforts by measuring caseload, conviction rates, criminal profiles, and international cooperation. It subsequently assesses the degree to which international influences, technical issues, and ethnic compositions have affected these results. This paper seeks to answer the following question that has relevance to other post-conflict nation-building efforts: Which factors have the most eroding effect on international criminal prosecutions? It concludes that

\footnotetext{
1 "Balkans War: A Brief Guide," BBC, March 18, 2016,

https://www.bbc.com/news/world-europe-17632399.

2 “About the ICTY," International Criminal Tribunal for the Former Yugoslavia, accessed on April 11, 2021, https://www.icty.org/en/about.

${ }^{3}$ Untied Nations, "Report of the International Tribunal for the Former Yugoslavia," August 1, 2017, 15, https://www.icty.org/x/file/About/Reports and Publications/AnnualReports/annual_report_2017_en.pdf.

${ }^{4}$ United Nations.

${ }^{5}$ United Nations, 13.

${ }^{6}$ United Nations, 15.

${ }^{7}$ United Nations.
} 
ethnic composition trumps international incentives, technical proficiency, and organisational effectiveness in determining war crimes prosecution outcomes.

\section{A Quantitative Analysis of War Crimes Prosecution: Serbia vs. BiH}

Both Serbia and $\mathrm{BiH}$ have a special department responsible for prosecuting the bulk of war crimes. The Serbian Office of the War Crimes Prosecutor (OWCP) was founded on 1 July $2003,{ }^{8}$ based on inter alia the principles of cooperation with the ICTY and independence from politics. ${ }^{9}$ The Bosnian Special Department for War Crimes was established within the Prosecutor's Office (PO) in December 2004, nearly 18 months later. ${ }^{10}$ However, in BiH, entity and district level courts have played an important role in bringing war crimes cases to completion, as have the Higher Court and Court of Appeal of Belgrade in Serbia. The following data primarily pertain to the OWCP and PO, but, for purposes of contextualisation, it also relates to the Higher Court and Court of Appeal of Belgrade as well as local Bosnian courts.

According to its website, the OWCP has concluded a total of 66 war crimes cases, convicting 83 accused and acquitting $49 .{ }^{11}$ It claims to currently be handling 13 cases comprising 43 defendants, and an additional 14 cases, with 74 defendants, at the investigative stage. ${ }^{12}$ European Union (EU) statistics show that an additional 2,382 cases remain at the preinvestigation stage. ${ }^{13}$ In addition to the OWCP, the War Crimes Department of the Higher Court and Court of Appeal of Belgrade conducted 26 cases between 2004 and 2013, which resulted in 55 convictions and 32 acquittals. ${ }^{14}$ The OWCP issued no indictments of its own in

\footnotetext{
8 "Foundation," Office of the War Crimes Prosecutor, accessed on December 1, 2019, https://www.tuzilastvorz.org.rs/en/about-us/foundation.

9 "Goals and Strategy," Office of the War Crimes Prosecutor, accessed on December 1, 2019, https://www.tuzilastvorz.org.rs/en/about-us/goals-and-strategy.

10 “Department I (Special Department for War Crimes)," The Prosecutor's Office of Bosnia and Herzegovina, accessed on December 1, 2019,

http://www.tuzilastvobih.gov.ba/?opcija=sadrzaj\&kat=2\&id=4\&jezik=e.

11 "Statistics," Office of the War Crimes Prosecutor, accessed on December 1, 2019, https://www.tuzilastvorz.org.rs/en/cases/statistics.

12 Office of the War Crimes Prosecutor.

${ }^{13}$ European Commission, "Serbia 2019 Report: Communication From the Commission to the
} European Parliament, the Council, the European Economic and Social Committee and the Committee of the Regions: 2019 Communication on EU Enlargement Policy," May 29, 2019, 18, https://ec.europa.eu/neighbourhood-enlargement/sites/near/files/20190529-serbia-report.pdf.

${ }^{14}$ Humanitarian Law Center, "Ten Years of War Crimes Prosecutions in Serbia: Contours of Justice: Analysis of the Prosecution of War Crimes in Serbia 2004-2013," 2014, 39, http://www.hlc-rdc.org/wpcontent/uploads/2014/10/Analiza_2004-2013_eng.pdf. 
$2016^{15}$ or 2017 , but instead only received cases by transferal from inter alia $\mathrm{BiH} .{ }^{16}$ Out of all the criminal cases filed in Serbia between 2003 and 2018, only 13 involved mid-level officials and virtually none high-ranking officers. ${ }^{17}$ The case against Yugoslav Army General Dragan Živanović constituted the only investigation into a high-level official. This investigation into the case was completed in 2016, but dropped in 2017 due to insufficient evidence to prosecute. ${ }^{18}$ Moreover, only one case ever concerned events that occurred on Serbian soil, and it was referred by the Croatian Prosecutor's office and involved a low-ranked police official. ${ }^{19}$

The official Bosnian PO website describes the department as "an institution with the highest number of defendants in the international context after World War II and the Nuremberg and Tokyo Tribunals." ${ }^{20}$ Between 2004 and 2018, 217 war crimes trials were completed at the national level, including a number of high-level cases. ${ }^{21}$ Between 2010 and 2018, the PO transferred an additional 501 cases to the entity and district courts of the Federation of Bosnia and Herzegovina, the Republika Srpska and Brcko. ${ }^{22}$

These statistics indicate the divergence in prosecutorial performance between Serbia and $\mathrm{BiH}$, on which this paper will further elaborate. $\mathrm{BiH}$ has consistently managed a significantly greater caseload than Serbia, while targeting perpetrators at different levels, including highranking officers, whereas Serbia has noticeably failed to hold higher-level officials accountable. This apparent lack of commitment to war crimes prosecution from Serbia is further reflected in the comparative number of requests for international assistance. The United Nations International Residual Mechanism for Criminal Tribunals (IRMCT), instituted in 2010 to take over the functions of the international tribunals for the former Yugoslavia and

\footnotetext{
${ }^{15}$ Humanitarian Law Center, "Report on War Crimes Trials in Serbia During 2016," 2017, 16, http://www.hlc-rdc.org/wp-content/uploads/2017/05/Izvestaj_o_sudjenjima_za_2016_eng.pdf.

${ }^{16}$ Humanitarian Law Center, "Report on War Crimes Trials in Serbia During 2019," 2019, 18 , http://www.hlc-rdc.org/wp-content/uploads/2019/05/Report-on-War-Crimes-Trials-in-Serbia.pdf.

${ }^{17}$ European Commission, "Serbia 2019 Report," 18.

${ }^{18}$ Humanitarian Law Center, "Report on War Crimes Trials in Serbia During 2019," 21.

19 "Cases," Office of the War Crimes Prosecutor.

20 “Department I (Special Department for War Crimes)," The Prosecutor's Office of Bosnia and

${ }^{21}$ Organisation for Security and Cooperation in Europe, "War Crimes Case Management at the Prosecutor's Office of Bosnia and Herzegovina," 2019, 5, https://www.osce.org/files/f/documents/6/9/423209.pdf.

${ }^{22}$ Organisation for Security and cooperation in Europe, 15.
} Herzegovina. 
Rwanda, ${ }^{23}$ received disproportionately fewer requests for assistance and witness protection from Serbia than it did from BiH. Between 2016 and 2017, BiH submitted 146 assistance and 37 witness protection requests, while Serbia submitted 3 and 1 respectively. ${ }^{24}$ Between 2017 and 2018, BiH issued 309 assistance and 3 witness protection requests, whereas Serbia only had 27 assistance requests. ${ }^{25}$ Finally, between 2018 and 2019, BiH submitted 156 assistance requests, compared to Serbia's $28 .^{26}$

Given that both Serbia and BiH have pledged cooperation to the ICTY and IRMCT, while also promising to meet the prosecution standards required for EU accession, one might expect similar levels of commitment to war crimes prosecutions. However, the data analysed above indicate that Serbia is not acting in accordance with these guarantees, whereas, despite certain inefficiencies, $\mathrm{BiH}$ is processing its international criminal caseload as required by international organisations.

\section{Explaining the Divergence}

Such a great discrepancy in prosecutorial performance calls for further exploration of potential variables. Three explanations are assessed here: a) external influence, b) technical and organisational impediments, and c) ethnic composition.

\section{a) External Influences}

The initial independent variables this paper will examine are regional relations and funding. Closer ties to regional institutions and greater quantities of funding might explain BiH's disproportionately larger caseload and stronger inclusion of higher-level perpetrators. The desire to accede to regional organisations might explain a greater commitment to fulfilling pledges of prosecuting war criminals.

\footnotetext{
${ }^{23}$ Giorgia Tortora, "The Mechanism for International Criminal Tribunals: A Unique Model and Some of Its Distinctive Challenges," American Society of International Law, April 6, 2017,

https://www.asil.org/insights/volume/21/issue/5/mechanism-international-criminal-tribunals.

${ }^{24}$ United Nations, "Fifth Annual Report of the International Residual Mechanism for Criminal Tribunals," 2017, 12, https://www.irmct.org/sites/default/files/documents/170801-fifth-annual-report-en.pdf.

${ }^{25}$ United Nations, "Sixth Annual Report of the International Residual Mechanism for Criminal Tribunals," 2018, 12, https://www.irmct.org/sites/default/files/documents/180801 -sixth-annual-report-en.pdf.

${ }^{26}$ United Nations, "Seventh Annual Report of the International Residual Mechanism for Criminal Tribunals," 2019, 12, https://www.irmct.org/sites/default/files/documents/190801-seventh-annual-report-en.pdf.
} 
NATO is an important regional organisation, of which $\mathrm{BiH}$ aspires to become a member. The country joined the Partnership for Peace programme in 2006 and established its first Individual Partnership Action Plan in 2008. ${ }^{27}$ In December 2018, NATO accepted the country's first Annual National Programme, building on the Individual Partnership Action Plan. ${ }^{28}$ However, the requirements for NATO membership concentrate on the military capabilities and the efficiency and transparency of states. ${ }^{29}$ As such, NATO membership does not seem to constitute a strong incentive for $\mathrm{BiH}$ to conduct large-scale and fair war crimes prosecutions. The fact that Serbia has expressed no interest in joining the organisation ${ }^{30}$ does not explain why the country is lagging behind in its prosecution efforts. However, Serbia's historical alliance with Russia might shed light on Serbia's lack of interest in closely complying with regional demands.

Russia has provided Serbia with support in a variety of ways, thus the country may not be as dependent on technical and financial assistance with other organisations. This can help explain Serbia's lack of international cooperation on the criminal prosecution front. Firstly, Russia has propagated anti-NATO sentiment in Serbia, ${ }^{31}$ which could explain an absence of Serbian desire for NATO membership. Secondly, and more importantly with regards to war crimes prosecutions, Russia has profiled itself as the primary provider of trade opportunities, aid, and military assistance, which might diminish Serbian incentives to attain EU membership. Russian influences in Serbia have heavily obscured the amount of European support the country receives in practice. For example, the Russian flag appears on billboards sponsored by Gazprom on highways that were in fact funded by the EU. In addition, $65 \%$ of Serbian trade is with the EU while only $6.7 \%$ is with Russia. In another vein, Serbian soldiers trained twenty times with NATO countries in 2017, whereas only two exercises occurred with Russia, and the

\footnotetext{
27 "Relations with Bosnia and Herzegovina," North Atlantic Treaty Organisation, December 6, 2018, https://www.nato.int/cps/en/natohq/topics_49127.htm.

${ }^{28}$ North Atlantic Treaty Organisation.

${ }^{29}$ North Atlantic Treaty Organisation.

${ }^{30}$ North Atlantic Treaty Organisation, "Relations with Serbia."

${ }^{31}$ Dusan Stojanovic, "Russia, Serbia Blame NATO for Kosovo Tensions," U.S. News \& World Report, March 29, 2019, https://www.usnews.com/news/world/articles/2019-05-29/russia-serbia-blame-nato-forkosovo-police-raid.
} 
EU offered fifty times as much aid to Serbia as Russia did in $2016 .{ }^{32}$ Distorted perceptions of Russian aid may decrease Serbia's motivations for EU accession and consequently for compliance with EU war prosecution requirements. Despite increasing attempts to assert its influence in $\mathrm{BiH}$ by infiltrating the country's intelligence service and supporting nationalist Croat and Serb leaders, ${ }^{33}$ Russia, as of yet, does not have the same power over BiH that it does over Serbia. Consequently, BiH might be more intent on bridging its EU accession gaps, since it does not have an alternative regional backer. This might increase BiH's incentives for meeting EU war prosecution demands.

Although Russian support could help inform why Serbia is less diligently seeking to meet its EU accession requirements, it is insufficient in explaining the comparative difference in war crimes prosecutions between Serbia and $\mathrm{BiH}$. This is because, contrary to what one might expect given its Russian support, Serbia receives more EU funding and is closer to being a full EU member than BiH. Serbia has been a candidate country since $2012 .{ }^{34}$ It signed the Stabilisation and Association Agreement in 2013 and had its first EU-Serbia Intergovernmental Conference in 2014. ${ }^{35}$ Between 2014 and 2020, Serbia received a total of $€ 1.5 \mathrm{bn}$, of which $€ 675 \mathrm{mn}$ went to governance and the rule of law. ${ }^{36} \mathrm{BiH}$, on the other hand, has remained a potential candidate since 2003, despite having signed the Interim Agreement on Trade and Trade-Related Issue in 2008 and the Stabilisation and Association Agreement in 2015. ${ }^{37}$ The country received nearly a third of Serbia's funding in that same time period, collecting a total

${ }^{32}$ Michael Birnbaum, "Russia’s Low-Cost Influence Strategy Finds Success in Serbia," Washington Post, October 3, 2018, https://www.washingtonpost.com/world/europe/russias-low-cost-influence-strategyfinds-success-in-serbia--with-the-help-of-fighter-jets-media-conspiracies-and-a-bikergang/2018/10/03/49dbf48e-8f47-11e8-ae59-01880eac5f1d_story.html.

${ }_{33}$ Mersiha Gadzo and Harun Karcic, "Bosnia as the New 'Battleground' Between NATO and Russia," Al Jazeera, July 7, 2019, https://www.aljazeera.com/indepth/features/bosnia-battleground-nato-russia190627202133942.html.

34 "Serbia," European Neighbourhood Policy and Enlargement Negotiations, accessed December 1, 2019, https://ec.europa.eu/neighbourhood-enlargement/countries/detailed-country-information/serbia_en.

${ }^{35}$ European Neighbourhood Policy and Enlargement Negotiations.

36 "Serbia on its European Path," European Neighbourhood Policy and Enlargement Negotiations, October 2019, https://ec.europa.eu/neighbourhood-enlargement/sites/near/files/near_factograph_serbia.pdf.

37 "Bosnia and Herzegovina," European Neighbourhood Policy and Enlargement Negotiations, accessed December 1, 2019,

https://ec.europa.eu/neighbourhood-enlargement/countries/detailed-country-information/bosniaherzegovina_en. 
of $€ 530 \mathrm{mn}$, of which $€ 326.48 \mathrm{mn}$ went to governance and the rule of law. ${ }^{38}$ This governance and rule of law funding is less than half of what Serbia receives, which might suggest that Serbia has more resources than $\mathrm{BiH}$ to pursue war crimes prosecutions. In fact, given that cooperation with international criminal tribunals has been a central point of accession negotiations with Serbia, ${ }^{39}$ the logical assumption might be that Serbia would be more eager to address this point, since it is closer to achieving full membership. However, the data suggest the opposite.

Data from the Organisation for Security and Cooperation in Europe (OSCE) yield more intuitive results. The mission in Serbia only has 124 posts, with a 2019 budget of $€ 6.259 \mathrm{mn}$, which is similar to the funding the country received from the OSCE over the last few years. ${ }^{40}$ The Bosnian mission, on the other hand, comprised 315.5 posts and had a 2019 budget of $€ 11.682 \mathrm{mn}$, which equally mirrors funding from past years. ${ }^{41}$ As such, BiH had nearly twice as much funding as Serbia. This is especially important to note because the funds for Serbia were meant to contribute to judiciary reforms, ${ }^{42}$ which could have a direct influence on war crimes prosecution efforts. However, the assistance for $\mathrm{BiH}$ focused more on issues of democracy as opposed to the rule of law. ${ }^{43}$ Despite receiving more funding, BiH might not necessarily see many changes in its judiciary as a result.

\section{b) Technical and Organisational Impediments}

The second variable this paper will assess as a potential explanation for the different caseloads and conviction rates of $\mathrm{BiH}$ and Serbia is technical or organisational impediments that result from the varying capabilities and degrees of complexity of the Serbian and Bosnian courts.

38 "Bosnia and Herzegovina on its European Path," European Neighbourhood Policy and Enlargement Negotiations, September 2019, https://ec.europa.eu/neighbourhoodenlargement/sites/near/files/near_factograph_bosnia_and_herzegovina.pdf.

${ }^{39}$ Jelena Subotic, "Truth, Justice, and Reconciliation on the Ground: Normative Divergence in the Western Balkans,” Journal of International Relations and Development 18, no. 3 (2015): 363, https://doi.org/10.1057/jird.2015.13.

${ }^{40}$ Organisation for Security and Cooperation in Europe, "Survey of OSCE Field Operations," 2019, 18, https://www.osce.org/cpc/74783?download=true.

${ }^{41}$ Organisation for Security and Cooperation in Europe, 13.

${ }^{42}$ Organisation for Security and Cooperation in Europe, 17.

${ }^{43}$ Organisation for Security and Cooperation in Europe, 12. 
The transfer of more cases by the ICTY to either the Serbian OWCP or Bosnian PO might cause the entity in question to process its total caseload more slowly, which in turn could explain lower numbers of completed cases. The ICTY referred a total of eight cases, involving 13 accused, to the courts of the former Yugoslavia. ${ }^{44}$ One of these, involving Rahim Ademi and Mirko Norac, Croatian nationals, was transferred to Croatia and is therefore beyond the scope of this paper. ${ }^{45}$ A second case concerned a Bosnian Serb, Nikola Kovačević, who committed atrocities in Croatia. ${ }^{46}$ This was the only case that the ICTY transferred to Serbia. Thus, the Serbian workload was not significantly expanded through international case transfers. Serbia originally charged Kovačević, but then ruled him unfit for trial. ${ }^{47}$ This creates a weak track record for Serbia when compared to $\mathrm{BiH}$. BiH managed five ICTY cases, three of which involved multiple defendants, all of them Bosnian Serbs, and convicted every single accused. Milorad Trbić, ${ }^{48}$ Mitar Rašević, ${ }^{49}$ Savo Todović, ${ }^{50}$ Gojko Janković, ${ }^{51}$ Radovan Stanković, ${ }^{52}$ Zeljko Mejakić, ${ }^{53}$ Momčilo Gruban, ${ }^{54}$ Dušan Fuštar, ${ }^{55}$ Duško Knežević, ${ }^{56}$ and Paško Lubićić. ${ }^{57}$ Given that $\mathrm{BiH}$ carried the brunt of international transfers, the argument of compounded caseload fails to elucidate Serbia's weaker prosecutorial performance.

\footnotetext{
44 "Transfer of Cases," International Criminal Tribunal for the Former Yugoslavia, accessed December 1 2019, https://www.icty.org/en/cases/transfer-cases.

45 The Communication Service of the International Criminal Tribunal for the Former Yugoslavia, “"MEDAK POCKET” (IT-04-78) ADEMI \& NORAC,” 2005, https://www.icty.org/x/cases/ademi/cis/en/cis_ademi_norac.pdf.

46 The Communication Service of the International Criminal Tribunal for the Former Yugoslavia, “"DUBROVNIK' (IT-01-42/2) VLADIMIR KOVAČEVIĆ," https://www.icty.org/x/cases/kovacevic_vladimir/cis/en/cis_kovacevic_vladimir.pdf.

47 The Communication Service of the International Criminal Tribunal for the Former Yugoslavia.

${ }^{48}$ The Communication Service of the International Criminal Tribunal for the Former Yugoslavia, “"SREBRENICA' (IT-05-88/1) MILORAD TRBIĆ,” https://www.icty.org/x/cases/trbic/cis/en/cis_trbic_en.pdf.

${ }^{49}$ The Communication Service of the International Criminal Tribunal for the Former Yugoslavia, “FOČA' (IT-97-25/1) RAŠEVIĆ \& TODOVIĆ,", https://www.icty.org/x/cases/todovic_rasevic/cis/en/cis_rasevic_todovic.pdf.

50 The Communication Service of the International Criminal Tribunal for the Former Yugoslavia.

${ }^{51}$ The Communication Service of the International Criminal Tribunal for the Former Yugoslavia, “"FOČA' (IT-96-23/2) JANKOVIĆ \& STANKOVIĆ,",

${ }^{52}$ The Communication Service of the International Criminal Tribunal for the Former Yugoslavia.

${ }^{53}$ The Communication Service of the International Criminal Tribunal for the Former Yugoslavia, ““OMARSKA CAMP \& KERATERM CAMP' (IT-02-65) MEJAKIĆ et A1.," https://www.icty.org/x/cases/mejakic/cis/en/cis_mejakic_al_en.pdf.

54 The Communication Service of the International Criminal Tribunal for the Former Yugoslavia.

55 The Communication Service of the International Criminal Tribunal for the Former Yugoslavia.

56 The Communication Service of the International Criminal Tribunal for the Former Yugoslavia.

57 The Communication Service of the International Criminal Tribunal for the Former Yugoslavia, “"LAŠVA VALLEY' (IT-00-41) PAŠKO LJUBIČIĆ,", https://www.icty.org/x/cases/ljubicic/cis/en/cis_ljubicic.pdf.
} 
An analysis of both countries' war crimes departments and wider judiciaries similarly shows Serbia faces significantly fewer obstacles to successful war crimes prosecutions, and where it does is often the result of conscious governmental choices. As of 2018, Serbia had 2,418 judges and 769 public prosecutors, as well as a judiciary budget of $€ 299 \mathrm{mn} .{ }^{58}$ This outnumbers the 1,013 Bosnian judges and 377 Bosnian prosecutors, as well as the Bosnian judiciary budget of $€ 122.2 \mathrm{mn} .{ }^{59}$ However, the OWCP only has a total of 27 staff members covering 18 different positions. ${ }^{60}$ The structure of the office means that if all positions, other than those of the deputy and assistant prosecutors, were only held by one person, the OWCP could only have a maximum of 11 prosecutors. In contrast, BiH's PO has a total of 25 prosecutors, as well as a chief prosecutor. ${ }^{61}$ It is clear that Serbia has specific policies towards war crimes prosecutions, which means that it has allocated minimal resources to the OWCP. As such, the problem might not be insufficient funding or staff as much as a refusal to accept responsibility, as will be discussed in section c) below.

Likewise, structural inefficiencies do not explain Serbia's low caseload and conviction rate. Just as the resources allocated to war crimes prosecutions were not an accurate representation of overall judiciary resources, the protracted delays in Serbia's war crimes trials ${ }^{62}$ do not mirror those in the broader judiciary. Serbia has a case clearance rate of $110.03 \%$ (meaning the country is processing more cases than it receives, thus combatting its backlog) and a total backlog of 78,135 cases. ${ }^{63} \mathrm{BiH}$, on the other hand, has a clearance rate of $105 \%$ and a total backlog of $2.2 \mathrm{mn}$ cases, almost thirty times as many. ${ }^{64}$ The lower clearance rate and much greater overall backlog of $\mathrm{BiH}$ would only explain weaker war crimes prosecutions by $\mathrm{BiH}$ in comparison to Serbia, presuming that these statistics are indicative of state capacity to prosecute war crimes.

\footnotetext{
${ }^{58}$ European Commission, “Serbia 2019 Report,” 16.

${ }^{59}$ European Commission, "Analytical Report: Communication from the Commission to the European Parliament and the Council: Commission Opinion on Bosnia and Herzegovina's Application for Membership of the European Union,” May 29, 2019, 35, https://ec.europa.eu/neighbourhoodenlargement/sites/near/files/20190529-bosnia-and-herzegovina-analytical-report.pdf.

60 “Organization," Office of the War Crimes Prosecutor, accessed December 1, 2019, https://www.tuzilastvorz.org.rs/en/about-us/organization.

61 "Chief Prosecutor," The Prosecutor's Office of Bosnia and Herzegovina, accessed December 1, 2019, http://www.tuzilastvobih.gov.ba/?opcija=sadrzaj\&kat=15\&id=93\&jezik=e.

62 Humanitarian Law Center, "Report on War Crimes Trials in Serbia During 2019," 8.

${ }^{63}$ European Commission, "Serbia 2019 Report," 17.

${ }^{64}$ European Commission, “Analytical Report,” 36.
} 
In fact, in addition to this, national war crimes prosecutions in $\mathrm{BiH}$ face further obstacles. Its reduction in caseload proceeds much more slowly than at the entity and district level. Between 2014 and 2018, the PO whittled 682 cases down to 489, a reduction of 193, whereas the entity and district courts moved from 541 to 205 cases, a reduction of $336 .{ }^{65}$ One procedural deficiency that may help explain the slower rate of processing national cases is the poor quality of indictments. In 2014, 33 out of 60 indictments were returned to the PO. ${ }^{66}$ In 2015, this was 22 out of $51 ;{ }^{67}$ in 2016,17 out of 38 ; and in 2018, 9 out of $27 .{ }^{68}$ All these elements would increase the likelihood of $\mathrm{BiH}$ falling behind Serbia, yet the opposite is the case. However, it is important to note that the EU granted the Bosnian judiciary $€ 14.96 \mathrm{mn}$ to pay for judges', prosecutors', and support staff's salaries, as well as material costs, with the aim of reducing the country's war crimes cases backlog. ${ }^{69}$ Yet, this funding, in addition to the country's judiciary budget, still does not come close to the resources of the Serbian court system.

Serbia and $\mathrm{BiH}$ both face certain organisational obstacles to more efficiently and effectively managing their war crimes cases. However, it would appear that $\mathrm{BiH}$ faces more institutionalised challenges than Serbia. BiH struggles with poor coordination between the PO and the Court of Bosnia and Herzegovina, which results in the PO working on cases that should be referred to entity and district courts. ${ }^{70}$ This results in an unnecessary loss of PO resources. ${ }^{71}$ The PO also faces case fragmentation, whereby it separates already existing cases. ${ }^{72}$ In recent years alone, the PO has thus generated 350 new cases. ${ }^{73}$ This increases the overall workload of the office, while also producing a repetition of efforts, which results in a further loss of efficiency and waste of resources. ${ }^{74}$ Where Bosnian prosecution processes inherently decrease the PO's ability to efficiently manage its war crimes cases, Serbia faces difficulties that reflect

${ }^{65}$ Organisation for Security and Cooperation in Europe, "War Crimes Case Management," 18.

${ }^{66}$ Organisation for Security and Cooperation in Europe, "Processing of War Crimes at the State Level in Bosnia and Herzegovina," 32, https://www.osce.org/bih/247221?download=true.

${ }^{67}$ Organisation for Security and Cooperation in Europe.

${ }^{68}$ Organisation for Security and Cooperation in Europe, "War Crimes Case Management," 26.

${ }^{69}$ Organisation for Security and Cooperation in Europe, 9.

${ }^{70}$ Organisation for Security and Cooperation in Europe, 25.

${ }^{71}$ Organisation for Security and Cooperation in Europe.

${ }^{72}$ Organisation for Security and Cooperation in Europe, 18.

${ }^{73}$ Organisation for Security and Cooperation in Europe.

${ }^{74}$ Organisation for Security and Cooperation in Europe. 
a lack of commitment to war crimes prosecutions as opposed to structural impediments like in BiH. Serbia's Prosecutorial Strategy does not provide the OWCP with guidelines on how to prioritise war crimes cases. ${ }^{75}$ In addition, between 1 January 2016 and 31 May 2017, all indictments and actions were undertaken by deputy war crimes prosecutors in the absence of an acting war crimes prosecutor, as a result of which charges brought in that period were dismissed and had to be reopened. ${ }^{76}$ All this suggests that Serbia is falling behind on war crimes case management due to a lack of engagement, whereas BiH's engagement is consistent but flawed due to a number of pragmatic problems.

\section{c) Ethnic Composition}

The third and final variable which calls for examination is the different ethnic compositions of Serbia and $\mathrm{BiH}$, to establish whether different perceptions of the war and responsibility have an impact on how intensively the countries are processing war crimes cases. Could diverging ethnic compositions of the two populations and the degree to which these were victimised during the war inform the different approaches to war crimes prosecutions in $\mathrm{BiH}$ and Serbia?

The geographical concentration of war crimes corresponds closely to the degree to which countries have pursued war crimes prosecutions. Out of the war crimes prosecuted before the ICTY, only one occurred in Serbia. ${ }^{77} \mathrm{BiH}$ was the site for over 50 of the cases prosecuted before the ICTY ${ }^{78}$ As the primary victim, it would be logical that the country would be more intent on procuring justice for the war crimes committed. This point is strengthened by the fact that ethnic Serbs were the primary perpetrators of war crimes. It also more generally suggests that larger numbers of war crimes victims in a country increases the likelihood of that country pursuing war crimes prosecutions, even if the perpetrators are citizens of that country. The absence of war crimes in Serbia would thus help to explain the apparently lower commitment to prosecuting war crimes.

\footnotetext{
${ }^{75}$ Humanitarian Law Center, "Report on War Crimes Trials in Serbia during 2019," 16.

${ }^{76}$ Humanitarian Law Center, 30.

77 “Interactive Map," International Criminal Tribunal for the Former Yugoslavia, accessed December 1, 2019, https://www.icty.org/en/cases/interactive-map.

${ }^{78}$ International Criminal Tribunal for the Former Yugoslavia.
} 
However, this picture becomes more complex when considering the war crimes that occurred in Kosovo. For the sake of this paper, we will consider Kosovo a part of Serbia, given Serbia's perception of the issue. Moreover, we choose to do so because if Serbia holds that Kosovo falls within its borders, then the victims of the war crimes committed there would constitute Serbian citizens. The ICTY prosecuted between 15-20 war crimes that occurred in Kosovo. ${ }^{79}$ Under the argument above, this would increase the incentives for Serbia to prosecute war criminals. The fact that they continue to do so comparatively less well than $\mathrm{BiH}$ therefore requires a further explanation. This paper proposes that the greater cohesion and potentially exclusionary nature of national and ethnic identity can elucidate this difference.

The different ethnic compositions of $\mathrm{BiH}$ and Serbia contribute to vastly different attitudes to the war and responsibility for war crimes between the two countries. As of 2013, $\mathrm{BiH}$ consisted of $48.4 \%$ Bosniaks, $32.7 \%$ Serbs and $14.6 \%$ Croats. $^{80}$ The fact that the majority group in the country corresponds to the group that was most intensely targeted in war crimes during the Bosnian war ( $80 \%$ of war casualties being Bosniaks ${ }^{81}$ ) could explain why $\mathrm{BiH}$ performs better in war crimes prosecutions. The desire to procure justice for war crimes victims is much more likely to be prevalent in the country that holds the majority of the victims.

This idea is reinforced by the analysis of cases referred to the two autonomous entities that make up BiH, i.e. the Federation of Bosnia and Herzegovina and the Republika Srpska (RS). ${ }^{82}$ The Federation comprises of $88.23 \%$ of the Bosnian Bosniaks, while the RS held $92.11 \%$ of Bosnian Serbs. ${ }^{83}$ Until 2017, the number of cases transferred to the RS hardly ever exceeded half that of those referred to the Federation. ${ }^{84}$ The lower number of cases received by the RS mirrors the lower levels of war crimes prosecutions in Serbia which was $83.3 \%$ Serb, and only

\footnotetext{
${ }^{79}$ International Criminal Tribunal for the Former Yugoslavia.

80 "People of Bosnia and Herzegovina," Encyclopaedia Britannica, accessed December 1, 2019, https://www.britannica.com/place/Bosnia-and-Herzegovina/People.

81 "Bosnia and Herzegovina, 1992-1995," United States Holocaust Memorial Museum, accessed

December 1, 2019, https://www.ushmm.org/genocide-prevention/countries/bosnia-herzegovina/case-

82 "Bosnia and Herzegovina," Encyclopaedia Britannica, accessed April 11, 2021, https://www.britannica.com/place/Bosnia-and-Herzegovina.

${ }^{83}$ Roldolfo Toè, “Census Reveals Bosnia's Changed Demography,” Balkan Insight, June 30, 2016, https://balkaninsight.com/2016/06/30/new-demographic-picture-of-bosnia-finally-revealed-06-30-

${ }^{84}$ Organisation for Security and Cooperation in Europe, "War Crimes Case Management,"15.
} study/background/1992-1995. 2016/. 
2.1\% Bosniak. ${ }^{85}$ The Serb majority in Serbia increased during the Bosnian war with the influx of Serb refugees from $\mathrm{BiH}$ and Croatia, and the relocation of many Bosniaks to $\mathrm{BiH}^{86}$ The dominance of ethnic Serbs in Serbia facilitates the promotion of Serb-centered narratives concerning the war, which have tended to involve very little acknowledgment of criminal responsibility. The war crimes prosecution efforts in Serbia suggest that the country has little interest in procuring justice for non-Serbs or in supporting processes that involve the possible indictment of ethnic Serbs, as demonstrated by EU and ICTY reports that note the lack of Serbian cooperation. In fact, a survey conducted after the arrest of Radovan Karadžić, the president of the RS during the Bosnian war, indicated that only $17 \%$ of the Serb responders considered the man a criminal, and that $86 \%$ considered the arrest a result of anti-Serb bias amid the ICTY. ${ }^{87}$ The continued denial of criminal responsibility by Serbs as a broader group is further reflected in the Republika Srpska's vote in 2018 to revoke its recognition of Srebrenica as a case of genocide. ${ }^{88}$

Many political scientists support the notion that the presence of a dominant core group can have nefarious effects on post-conflict justice. Professor Jelena Subotic argues that national identity has the ability to block international justice interventions and generate resistance thereto. ${ }^{89}$ She suggests that in multi-ethnic contexts, justice only means "justice for crimes committed against oneself or one's ethnic group, but not justice for crimes committed in one's name or the name of the group one belongs to." ${ }^{90}$ Former prosecutor with the ICTY, Dan Saxon, further proposes that none of the three dominant ethnic groups perceives themselves as

85 "People of Serbia," Encyclopaedia Britannica, accessed December 1 2019, https://www.britannica.com/place/Serbia/People.

${ }^{86}$ Encyclopaedia Britannica.

87 Jelena Subotic, "Expanding the Scope of Post-Conflict Justice: Individual, State and Societal Responsibility for Mass Atrocity," Journal of Peace Research 48, no. 2 (March 1, 2011): 158, https://doi.org/10.1177/0022343310394696.

${ }^{88}$ Lisa Schlein, "Serb Rejection of Report on Srebrenica Massacre Sows Division," Voice of America, August 19, 2018, https://www.voanews.com/europe/serb-rejection-report-srebrenica-massacre-sows-division.

${ }^{89}$ Jelena Subotic, "Truth, justice, and Reconciliation on the Ground: Normative Divergence in the Western Balkans,” Journal of International Relations and Development 18, no. 3 (2015): 364, https://doi.org/10.1057/jird.2015.13.

90 Subotic, 367. 
perpetrators. ${ }^{91}$ Across the former Yugoslavia, these ethnicity-based perceptions of justice and responsibility persist. However, the greater ethnic diversity and disaggregation in $\mathrm{BiH}$ have impeded the creation of a single national identity.

The large numbers of war crimes that occurred around $\mathrm{BiH}$ and domestic disagreements on responsibility mean that no single and sufficiently strong ideological obstacle stands in the way of war crimes prosecutions. In Serbia, on the other hand, the prevalence of Serbs means that this group's experience and estimation of its criminal responsibility, whether as Serbian Serbs or Bosnian Serbs, defines the country's evidently reluctant policy on war crimes prosecutions.

\section{Conclusion}

When analysing the data concerning the support Serbia and BiH enjoy from international and regional organisations, as well as the countries' judicial capabilities and the cohesion of both national identities, Serbia appears capable of outperforming $\mathrm{BiH}$ in prosecuting war criminals. However, OWCP and OP data, as well as ICTY reporting, produce the opposite picture. Despite receiving significantly more EU funding and being closer to EU membership than $\mathrm{BiH}$, Serbia has done less than $\mathrm{BiH}$ to meet the $\mathrm{EU}$ war crimes prosecution requirements.

A number of factors emerge to explain this. Firstly, due to Russian support, Serbia might feel a less pressing need to comply with EU war crimes prosecution requirements, despite receiving disproportionately more aid from the EU. Secondly, Serbia's tendency to prioritise the protection of its nationals over countering impunity has created an environment in which war prosecutions do not flourish. Although its judiciary has significantly fewer resources and capabilities than Serbia, $\mathrm{BiH}$ continues to give higher priority to convicting Bosnian war criminals.

One might argue that the larger number of war crimes in Bosnia automatically means that more war crimes prosecutions should take place in the country. Yet, not only did Bosnian Serb forces perpetrate atrocities with the support from Serbia, but the Bosnian population today is

${ }^{91}$ Dan Saxon, "Exporting Justice: Perceptions of the ICTY Among the Serbian, Croatian, and Muslim Communities in the Former Yugoslavia," Journal of Human Rights 4, no. 4 (October 2005): 562. https://doi.org/10.1080/14754830500332837. 
still around one-third Serb. This research is therefore still necessary to demonstrate why this significant Serb presence and influence in $\mathrm{BiH}$ has not impeded prosecution efforts as it has in Serbia. This paper finds the balance of Serbs in relation to other ethnic groups to be crucial. Although the fragmented national identity of $\mathrm{BiH}$ has harmed its progress as a new nation, it has created favourable conditions for war crimes prosecutions.

The different approaches of these ex-Yugoslav states to domestic as well as international war crimes prosecutions provide valuable lessons about the challenges in producing postconflict justice. This research suggests that states in which the political and national units are more separated might be those in which war crimes prosecutions can be most effectively implemented.

\section{Bibliography}

BBC. “Balkans War: A Brief Guide.” March 18, 2016. https://www.bbc.com/news/worldeurope-17632399.

\section{Birnbaum, Michael. "Russia's Low-Cost Influence Strategy Finds Success in Serbia."} Washington Post, October 3, 2018. https://www.washingtonpost.com/world/europe/russias-low-cost-influence-strategyfinds-success-in-serbia--with-the-help-of-fighter-jets-media-conspiracies-and-a-bikergang/2018/10/03/49dbf48e-8f47-11e8-ae59-01880eac5f1d_story.html.

Encyclopaedia Britannica. "Bosnia and Herzegovina." Accessed April 11, 2021. https://www.britannica.com/place/Bosnia-and-Herzegovina.

Encyclopaedia Britannica. "People of Bosnia and Herzegovina." Accessed December 1, 2019. https://www.britannica.com/place/Bosnia-and-Herzegovina/People.

Encyclopaedia Britannica. "People of Serbia." Accessed December 1, 2019. https://www.britannica.com/place/Serbia/People.

European Commission. "Analytical Report: Communication from the Commission to the European Parliament and the Council: Commission Opinion on Bosnia and Herzegovina's Application for Membership of the European Union,” 2019. https://ec.europa.eu/neighbourhood-enlargement/sites/near/files/20190529-bosniaand-herzegovina-analytical-report.pdf. 
European Commission. "Serbia 2019 Report: Communication from the Commission to the European Parliament, the Council, the European Economic and Social Committee and the Committee of the Regions: 2019 Communication on EU Enlargement Policy." 2019. https://ec.europa.eu/neighbourhood-enlargement/sites/near/files/20190529serbia- report.pdf.

European Neighbourhood Policy and Enlargement Negotiations. "Serbia on its European Path." October 2019. https://ec.europa.eu/neighbourhoodenlargement/sites/near/files/near_factograph_serbi a.pdf.

European Neighbourhood Policy and Enlargement Negotiations. "Bosnia and Herzegovina on its European Path.” September 2019. https://ec.europa.eu/neighbourhoodenlargement/sites/near/files/near_factograph_bosnia_and_herzegovina.pdf.

European Neighbourhood Policy and Enlargement Negotiations. "Bosnia and Herzegovina." Accessed December 1, 2019. https://ec.europa.eu/neighbourhoodenlargement/countries/detailed-country-information/bosnia-herzegovina_en.

European Neighbourhood Policy and Enlargement Negotiations. "Serbia." Accessed December 1, 2019. https://ec.europa.eu/neighbourhoodenlargement/countries/detailed-country-information/serbia_en.

Gadzo, Mersiha and Karcic, Harun. "Bosnia as the New 'Battleground' Between NATO and Russia.” Al Jazeera, July 7, 2019. https://www.aljazeera.com/indepth/features/bosniabattleground-nato-russia-190627202133942.html.

Humanitarian Law Center. "Report on War Crimes Trials in Serbia During 2019.” 2019. http://www.hlc-rdc.org/wp-content/uploads/2019/05/Report-on-War-Crimes-Trialsin-Serbia.pdf.

Humanitarian Law Center. "Report on War Crimes Trials in Serbia During 2016.” 2017. http://www.hlcrdc.org/wpcontent/uploads/2017/05/Izvestaj_o_sudjenjima_za_2016_eng.pdf.

Humanitarian Law Center. "Ten Years of War Crimes Prosecutions in Serbia: Contours of Justice: Analysis of the Prosecution of War Crimes in Serbia 2004-2013."2014. http://www.hlc-rdc.org/wp-content/uploads/2014/10/Analiza_2004-2013_eng.pdf.

International Criminal Tribunal for the Former Yugoslavia. "About the ICTY." Accessed April 11, 2021. https://www.icty.org/en/about.

International Criminal Tribunal for the Former Yugoslavia. "Interactive Map.” Accessed December 1, 2019. https://www.icty.org/en/cases/interactive-map. 
International Criminal Tribunal for the Former Yugoslavia. "Transfer of Cases." Accessed December 1, 2019. https://www.icty.org/en/cases/transfer-cases.

North Atlantic Treaty Organisation. "Relations with Bosnia and Herzegovina." Accessed December 1, 2019. https://www.nato.int/cps/en/natohq/topics_49127.htm.

North Atlantic Treaty Organisation. "Relations with Serbia." Accessed December 1, 2019. https://www.nato.int/cps/en/natohq/topics_50100.htm.

Office of the War Crimes Prosecutor. "Cases.” Accessed December 1, 2019. https://www.tuzilastvorz.org.rs/en/cases/case-name-sremska-mitrovica.

Office of the War Crimes Prosecutor. "Foundation.” Accessed December 1, 2019. https://www.tuzilastvorz.org.rs/en/about-us/foundation.

Office of the War Crimes Prosecutor. "Goals and Strategy.” Accessed December 1, 2019. https://www.tuzilastvorz.org.rs/en/about-us/goals-and-strategy.

Office of the War Crimes Prosecutor. “Organization.” Accessed December 1, 2019. https://www.tuzilastvorz.org.rs/en/about-us/organization.

Office of the War Crimes Prosecutor. "Statistics." Accessed December 1, 2019. https://www.tuzilastvorz.org.rs/en/cases/statistics.

Organisation for Security and Cooperation in Europe. "Processing of War Crimes at the State Level in Bosnia and Herzegovina." https://www.osce.org/bih/247221?download=true.

Organisation for Security and Cooperation in Europe. "Survey of OSCE Field Operations." 2019. https://www.osce.org/cpc/74783?download=true.

Organisation for Security and Cooperation in Europe. "War Crimes Case Management at the Prosecutor's Office of Bosnia and Herzegovina.” 2019. https://www.osce.org/mission-to-bosnia-and-herzegovina/423209?download=true.

Saxon, Dan. "Exporting Justice: Perceptions of the ICTY Among the Serbian, Croatian, and Muslim Communities in the Former Yugoslavia." Journal of Human Rights 4, no. 4 (October 2005): 559-572. https://doi.org/10.1080/14754830500332837.

Schlein, Lisa. "Serb Rejection of Report on Srebrenica Massacre Sows Division.” Voice of America. August 19, 2018. https://www.voanews.com/europe/serb-rejection-reportsrebrenica-massacre-sows-division. 
Stojanovic, Dusan. "Russia, Serbia Blame NATO for Kosovo Tensions." U.S. News \& World Report, March 29, 2019. https://www.usnews.com/news/world/articles/2019-0529/russia-serbia-blame-nato-for-kosovo-police-raid.

Subotic, Jelena. "Expanding the Scope of Post-Conflict Justice: Individual, State and Societal Responsibility for Mass Atrocity." Journal of Peace Research 48, no. 2 (March 2011): 157-169. https://www.jstor.org/stable/29777500.

Subotic, Jelena. "Truth, Justice, and Reconciliation on the Ground: Normative Divergence in the Western Balkans." Journal of International Relations and Development 18, no. 3 (2015): 361-382. https://doi.org/10.1057/jird.2015.13.

The Communication Service of the International Criminal Tribunal for the Former Yugoslavia. "'MEDAK POCKET' (IT-04-78) ADEMI \& NORAC," https://www.icty.org/x/cases/ademi/cis/en/cis_ademi_norac.pdf.

The Communication Service of the International Criminal Tribunal for the Former Yugoslavia. "“FOČA' (IT-96-23/2) JANKOVIĆ \& STANKOVIĆ," https://www.icty.org/x/cases/stankovic/cis/en/cis_jankovic_stankovic_en.pdf.

The Communication Service of the International Criminal Tribunal for the Former Yugoslavia. 'OMARSKA CAMP \& KERATERM CAMP' (IT-02-65) MEJAKIĆ et Al.," https://www.icty.org/x/cases/mejakic/cis/en/cis_mejakic_al_en.pdf.

The Communication Service of the International Criminal Tribunal for the Former Yugoslavia. "'SREBRENICA' (IT-05-88/1) MILORAD TRBIĆ," https://www.icty.org/x/cases/trbic/cis/en/cis_trbic_en.pdf.

The Communication Service of the International Criminal Tribunal for the Former Yugoslavia. " "LAŠVA VALLEY' (IT-00-41) PAŠKO LJUBIČIĆ," https://www.icty.org/x/cases/ljubicic/cis/en/cis_ljubicic.pdf.

The Communication Service of the International Criminal Tribunal for the Former Yugoslavia. "FOČA' (IT-97-25/1) RAŠEVIĆ \& TODOVIĆ," https://www.icty.org/x/cases/todovic_rasevic/cis/en/cis_rasevic_todovic.pdf.

The Communication Service of the International Criminal Tribunal for the Former Yugoslavia. "“DUBROVNIK' (IT-01-42/2) VLADIMIR KOVAČEVIĆ." https://www.icty.org/x/cases/kovacevic_vladimir/cis/en/cis_kovacevic_vladimir.pdf.

The Prosecutor's Office of Bosnia and Herzegovina. "Chief Prosecutor." Accessed December 1, 2019. http://www.tuzilastvobih.gov.ba/?opcija=sadrzaj\&kat=15\&id=93\&jezik=e. 
The Prosecutor's Office of Bosnia and Herzegovina. "Department I (Special Department for War Crimes)." Accessed December 1, 2019. http://www.tuzilastvobih.gov.ba/?opcija=sadrzaj\&kat=2\&id=4\&jezik=e.

Toè, Roldolfo. “Census Reveals Bosnia's Changed Demography.” Balkan Insight, June 30, 2016. https://balkaninsight.com/2016/06/30/new-demographic-picture-of-bosniafinally-revealed-06-30-2016/.

Tortora, Giorgia. "The Mechanism for International Criminal Tribunals: A Unique Model and Some of Its Distinctive Challenges." American Society of International Law, April 6, 2017. https://www.asil.org/insights/volume/21/issue/5/mechanisminternational-criminal-tribunals.

United Nations. "Fifth Annual Report of the International Residual Mechanism for Criminal Tribunals," 2017. https://www.irmct.org/sites/default/files/documents/170801-fifthannual-report-en.pdf.

United Nations. "Report of the International Tribunal for the Former Yugoslavia." 1 August 2017.

https://icty.org/x/file/About/Reports\%20and\%20Publications/AnnualReports/annualre port_2017_en.pdf.

United Nations. "Seventh Annual Report of the International Residual Mechanism for Criminal Tribunals." 2019. https://www.irmct.org/sites/default/files/documents/190801-seventh-annual-reporten.pdf.

United Nations. "Sixth Annual Report of the International Residual Mechanism for Criminal Tribunals.” 2018. https://www.irmct.org/sites/default/files/documents/180801-sixthannual-report-en.pdf.

United States Holocaust Memorial Museum. "Bosnia and Herzegovina, 1992-1995." Accessed December 1, 2019. https://www.ushmm.org/genocideprevention/countries/bosnia-herzegovina/case-study/background/1992-1995.

https://www.osce.org/mission-to-bosnia-and-herzegovina/423209?download=true. 